\title{
ジルコニアと金属チタンの無加圧接合
}

\author{
小暮 英治 $・$ 星 野浩邦・飯田 武揚・三田村 孝 \\ (埼玉大学工学部応用化学科, 388 浦和市下大久保 255)
}

\section{Pressureless Bonding of 3Y-TZP to Titanium}

\author{
Eiji KOGURE ${ }^{\dagger}$, Hirokuni HOSHINO, Takeaki IIDA and Takashi MITAMURA
}

(Department of Applied Chemistry, Faculty of Engineering, Saitama University, 255, Shimo-ohkubo, Urawa-shi

338)

\begin{abstract}
The pressureless bonding of $3 \mathrm{Y}-\mathrm{TZP}$ and Ti metal using a bonding agent containing $\mathrm{Cu}_{2} \mathrm{O}$-added 5 wt \% activated carbon as a reductant has been investigated. The test specimen consisting of two kinds of the materials in question with the bonding agent interposed between the two has been heat-treated at $1000^{\circ} \mathrm{C}$ for $0 \mathrm{~min}$ to $8 \mathrm{~h}$, exposed in an argon stream. The average strength of the test specimens bonded under the conditions of $4^{\circ} \mathrm{C} /$ min of heating rate and $30 \mathrm{~min}$ of treatment time was 53 $M P a$. An observation of the interfacial composition and an analysis of the micro-constituents have been performed with the bonded body thus obtained, employing EPMA and SEM with an energy-dispersive-type X-ray analyser. As the result, Cu produced by the carbon reduction of $\mathrm{Cu}_{2} \mathrm{O}$ is diffused into the Ti metal to form $\mathrm{CuTi}_{2}$. It has been made known that the structure of the bonded interface comprised of plural layers is as shown below. The reaction layers from $3 Y$-TZP sequential to $\mathrm{Ti}$ metal are titanium oxides layer $\left(\mathrm{TiO}, \mathrm{Ti} \mathrm{i}_{2} \mathrm{O}\right.$ )/ Ti-rich layer ( $\mathrm{Ti}$ with scanty $\left.\mathrm{Cu}\right) / \mathrm{Cu}-\mathrm{Ti}$ alloy layer $\left(\mathrm{CuTi}_{2}\right.$ ). The most effective parameters affecting the bonding strength are surface roughness of TZP and heating rate when heat-treatment is conducted. The bonding strength obtained by utilizing a specimen of TZP with $3 \mu \mathrm{m}$ of surface roughness and $20^{\circ} \mathrm{C} / \mathrm{min}$ of heating rate for $30 \mathrm{~min}$ of treatment time was higher than $110 \mathrm{MPa}$. None of strength degradation has been noticed at all with the bonding strength of the bonded bodies thus obtained in $\mathrm{Ar}$ gas, $N_{2}$ gas, and the air up to $1000^{\circ}, 800^{\circ}$ and $400^{\circ} \mathrm{C}$, respectively. The result implies that the bonded bodies are thermally stabilized.
\end{abstract}

[Received March 4, 1988; Accepted July 22, 1988]

Key-words : Pressureless bonding, 3 Y-TZP, Titanium, Bonding strength, Tensile test

\section{1. 緒 言}

最近，セラミックスと金属の異種材料間の接合技術に 関する報告が増えてはいるものの, 接合に要するプロセ スが多く，単純な形状をしたものに限定されている．そ のため特殊な形状をしたものや大型形状といった材料同 士の接合にはいまだに問題が残されている.

酸化物セラミックスと金属の接合では固相接合 法 $^{1 / 26}$, 反応接合法 ${ }^{71}$, 液相接合法 ${ }^{8)}$ が主流である. し かし, 酸化物七ラミックスの接合例は従来より主にアル ミナ (以下 $\mathrm{Al}_{2} \mathrm{O}_{3}$ とする) に関するものであるが, 最近 ではジルコニア (以下 $\mathrm{ZrO}_{2}$ とする) に関する接合例も 比較的多く認められる ${ }^{9}$. 中でも酸化イットリウム (以 下 $\mathrm{Y}_{2} \mathrm{O}_{3}$ とする) を $3 \mathrm{~mol} \%$ 含む正方晶 $\mathrm{ZrO}_{2}$ 多結晶体 (以下 $3 \mathrm{Y}-\mathrm{TZP}$ と略す) が高強度, 高靱性セラミック スの代表的なものであり ${ }^{10)}$, 今後ますますその拡大する 用途への期待は大きい.

そこで著者らは，これまでに無加圧下で $3 Y$-TZP と 金属材料として最も注目されており，接合報告例の少な

現在：日産自動車 (株) テクニカルセンター, 243-01 厚木 市岡津古久 560-2

Now with Technical Center, Nissan Motor Co., Ltd., 560-2, Okatsukoku, Atsugi-shi 243-01
い金属チタン（以下 $\mathrm{Ti}$ と略する）との接合に関してい

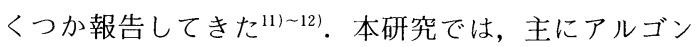
雲囲気下, 比較的低温度において, 亜酸化銅 (以下 $\mathrm{Cu}_{2} \mathrm{O}$ とする) に所定量の活性炭を添加したものを接合 剂に用いて, 無加圧下で $3 \mathrm{Y}-\mathrm{TZP}$ と Ti との接合を行っ た. その際の合成䨌囲気, $\mathrm{ZrO}_{2}$ 面粗さなよ゙の接合強度 に及ぼす影響について検討し, 併せて接合機構を考察し たので報告する.

\section{2. 実験方法}

\section{1 接合材}

母材として用いた $\mathrm{ZrO}_{2}$ 焼結体は, $3 \mathrm{Y}$-TZP 粉末（東 ソ一製, 粒径 $0.1 \sim 0.2 \mu \mathrm{m})$ をラバープレスで均一に成 形したもの (成形圧; $1 \mathrm{t} / \mathrm{cm}^{2}$ ) を空気中, 常圧で $1500^{\circ} \mathrm{C}$, $2 \mathrm{~h}$ で焼成したものを用いた $(4 \times 5 \times 10 \mathrm{~mm}$, 相対密度 $99 \%$ 以上). また, 比較のために各種焼成温度で焼成し たものも併せて用いた。

金属 Ti は純 Ti (高純度化学研究所製, 純度 $99.9 \%$ 以上）と JIS 規格 2 種相当品（純度 $99 \%$ ）の 2 種類で, $5 \phi \times 5 \mathrm{~mm}$ の円柱タブレットを用いた。 これらの接合 材は, 接合面を $1 \mu \mathrm{m}$ のダイヤモンドペーストを用いて 鏡面仕上げした。なお，比較のために $\mathrm{ZrO}_{2}$ 接合材にか 
ぎり，\#50～\#200のダイヤモンド砫石並びに 1９ 9 m の各粒度のダイヤモンドペーストを用いて種々の面粗さ に仕上げた，表面研削及び研磨した接合材は，表面の不 純物を除去するためにエタノールとアセトン混合液（混 合比 $1: 1$ ) 中にて超音波洗浄器で洗浄した後, 水洗, 乾燥させた。

\section{2 接合体の合成}

接合に用いた接合剂は最も良好な接合強度が得られた $\mathrm{Cu}_{2} \mathrm{O}^{111}$ に還元率として $5 \mathrm{wt} \%$ 活性炭を混合し，エチ レングリコールを加えてペースト状にしたものを用い た。この接合剤を Ti，3Y-TZP との間に塗布し，石英 ガラス反応管 $(30 \mathrm{~mm} \phi$, 長さ $350 \mathrm{~mm})$ に納めアルゴ ンガス気流中（比較のために窒素ガス気流中でも行う. ガス流量 $200 \mathrm{ml} / \mathrm{min}$ ), カンタル線抵抗加熱型管状炉 (内 径 $35 \mathrm{~mm} \phi$, 炉長 $300 \mathrm{~mm}$ ) で接合体を合成した。接合は, 昇降温速度 $4 \sim 30^{\circ} \mathrm{C} / \mathrm{min}$, 熱処理時間 $0 \mathrm{~min} \sim 8 \mathrm{~h}$ の条 件で行い，試料は炬が室温になった時点で取り出した。 なお，接合温度は最適温度である $1000^{\circ} \mathrm{C}$ と一定にした。 ここで熱処理時間 $0 \mathrm{~min}$ とは $1000^{\circ} \mathrm{C}$ まで所定速度で昇 温させた後, 直ちに同じ速度で降温する操作を指してい る.

\section{3 接合強度測定}

接合強度は，島津製作所製，オートグラフ IS-5000 型を用い，引張試験法によって評価した。接合体界面に 垂直な引張応力が加わるように所定の治具に装着してク ロスヘッドスピード $0.5 \mathrm{~mm} / \mathrm{min}$ で, 空気中, 室温で 測定した。引張強度は，破断荷重を接合面積で割った值 とし，信頼性を考虑して 1 バッチ最低 10 サンプルの平 均值として算出した。

\section{4 接合体の解析方法}

接合体界面の組織観察及び元素分析は，X 線マイク ロアナライザー (EPMA)-走查型電子顕微鏡 (SEM) (島津製作所 EMX-SM 型) 亡エネルギー分散型 X 線分 析装置 (EDAX) (Kevex Delta System) を備光た分析 型電子顕微鏡（日立製作所 S-2300 型）を用いて行った。 接合体をエポキシ樹脂に包埋し，接合体界面に垂直な方 向に切断し， $1 \mu \mathrm{m}$ のダイヤモンドペーストで研磨する ことにより観察用試料とした。また，接合体断面の界面 組成の検出及び同定には, 微小部 X 線回折装置（理学 電機製，PSPC/NDG システム）により行った。

\section{1 接合剤としての $\mathrm{Cu}_{2} \mathrm{O}$}

接合強度に及ぼす接合剤の影響について $\mathrm{Cu}_{2} \mathrm{O}$, 酸化 銅 (以下, $\mathrm{CuO}$ とする), 金属銅粉末 (以下, $\mathrm{Cu}$ 粉末 とする）を用いて比較検討した。なお，Cu 粉末以外の 接合剤には，還元剤として活性炭を $5 \mathrm{wt} \%$ 混合した。 接合時の昇降温速度は, $4^{\circ} \mathrm{C} / \mathrm{min}$, 接合温度は $1000^{\circ} \mathrm{C}$
と一定にした。結果を図 1 に示す。図より明らかなよう に接合剂として $\mathrm{Cu}_{2} \mathrm{O}$ が適切であることがわかる. 金属 $\mathrm{Cu}$ を用いた場合，熱処理時間 $0 \mathrm{~min}$ で平均 $13 \mathrm{MPa}$, $\mathrm{CuO}$ を用いた場合, $30 \mathrm{~min}$ で平均 $11 \mathrm{MPa}$ ，それに対 して $\mathrm{Cu}_{2} \mathrm{O}$ では $30 \mathrm{~min}$ で平均 $53 \mathrm{MPa}$ の接合強度が得 られた。このことは，接合界面において酸化物の還元に よって生成した金属 $\mathrm{Cu}$ 成分が $\mathrm{Cu}$ 粉末よりも活性な状 態で作用することを示唆するものである，また，同じ酸 化物でも $\mathrm{Cu}_{2} \mathrm{O}$ が効果的であるのは単位質量当たりの $\mathrm{Cu}$ 成分の占める割合が高く，還元された金属 $\mathrm{Cu}$ 成分 が十分に接合に寄与するためであろうと思われる。接合 凨として金属 $\mathrm{Cu}$ 成分を用いる方法はいくつかあるが， Cowan ${ }^{13)} \mathrm{Cu}_{2} \mathrm{O}$ 粉末と微量の $\mathrm{Al}_{2} \mathrm{O}_{3}$ 粉末を混合した ものを空気中で $1250^{\circ} \mathrm{C}, 30 \mathrm{~min}$ 加熱融解さ甘, 更に還

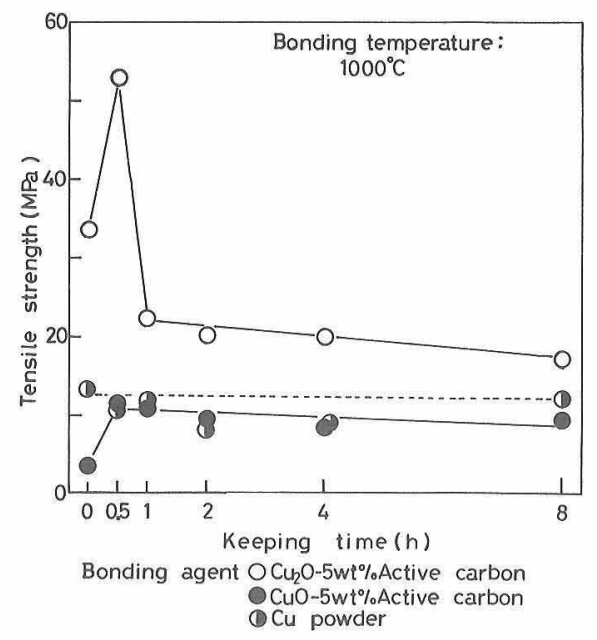

Fig. 1. Effect of bonding agent on bonding strength.

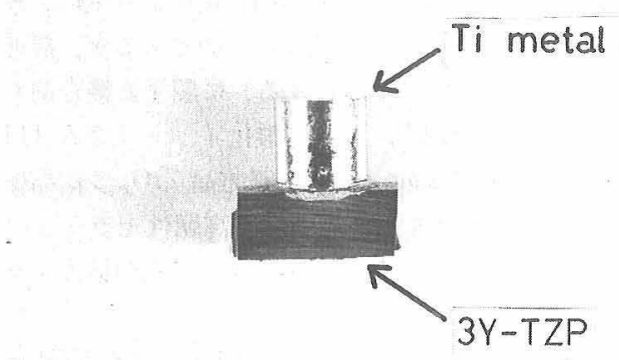

$10 \mathrm{~mm}$

Fig. 2. A $3 \mathrm{Y}-\mathrm{TZP} / \mathrm{Ti}$ joint. 
元䨌囲気で約 $1000^{\circ} \mathrm{C}$ に加熱して $\mathrm{Cu}$ 成分をメタライズ 処理した後，ろう付け法により金属とセラミックスを接 合している. 本接合法ではこうした複数のプロセスを経 なくても簡単に接合が可能で, しかも比較的低温度及び 短時間で接合できる利点を持っている. $\mathrm{Cu}_{2} \mathrm{O}$ を用いて 最適条件で接合した試料の全体の写真を図 2 に示す. 通 常異種材料間の熱膨張係数の相違に起因する熱応力が直 接セラミックス接合界面に生じるために，図2 のような 形態で接合用金属を直接セラミックスに接合するのはま れである。

\section{2 接合強度に及ぼす金属 $\mathrm{Ti}$ の純度の影響}

2 種類の $\mathrm{Ti}$ を用いて接合温度 $1000^{\circ} \mathrm{C}$, 昇降温速度 $4^{\circ} \mathrm{C} / \mathrm{min}$ と一定にし，アルゴン雾囲気中で接合した. 結果を図 3 に示す。金属の純度が強度に及ぼす影響は非 常に大きく, JIS 規格 2 種の Ti では, 処理時間 $30 \mathrm{~min}$ における最適条件でも平均 $28 \mathrm{MPa}$ となり, 純 $\mathrm{Ti}$ 接合 体のほぼ半分の強度となった。また，金属の純度によら ず $30 \mathrm{~min}$ 以上の熱処理は接合強度を低下させたが，こ れは界面組織と密接な関係があった. 界面の SEM 観察 により界面組織は熱処理時間の増加に伴ってポーラスな 組織が顕著となり，破断はこのポアーに沿って進行する

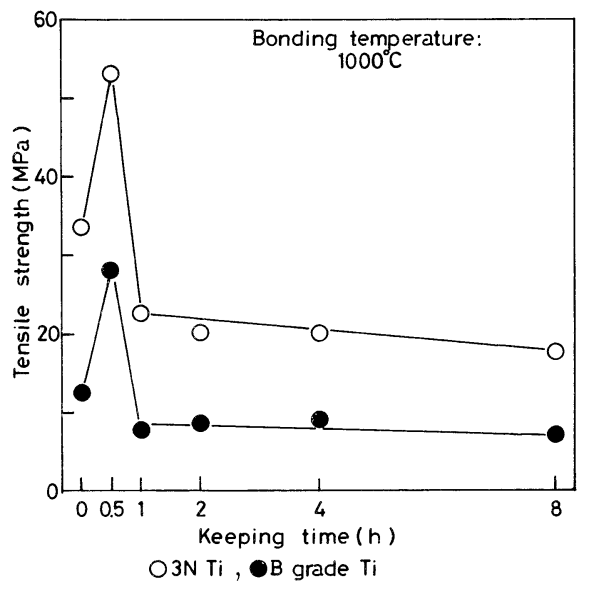

Fig. 3. Effect of titanium purity on bonding strength.

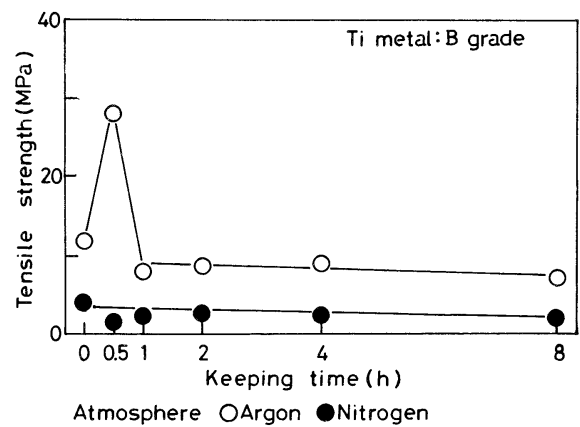

Fig. 4. Effect of bonding atmosphere on bonding strength.
ことが確認された。

\section{3 接合強度に及ぼす合成雾囲気の影響}

接合時における合成雾囲気が接合強度に及ぼす影響に ついて調査した，用いた金属は JIS 規格 2 種相当品で あり，温度 $1000^{\circ} \mathrm{C}$ と一定にして接合体を合成した。用 いた雾囲気用ガスは純度 $99.99 \%$ の窒素とアルゴンで ある．接合強度と熱処理時間の関係を図 4 に示す，図か らも明らかなように窒素雱囲気中ではほとんど強度を発 現しておらず，熱処理時間を変化させても数 MPa 程度 の接合強度にすぎない，EPMA-SEM による接合体断 面の組織観察並びに元素分析の結果, 界面に脆い組織が 確認され，その点を中心に破断していた。この脆い組織 はPSPC で同定したところ $\mathrm{TiN} と \mathrm{Ti}_{2} \mathrm{~N}$ の混合物で あった。よって合成雾囲気には特に Ti と反応すること のない，不活性雾囲気であるアルゴンガス下での接合が 適切であることがわかった。

\section{4 接合強度に及ぼす 3 Y-TZP 焼結体中に分散した $\mathrm{Al}_{2} \mathrm{O}_{3}$ 粒子の影響}

用いた接合材は $3 \mathrm{Y}-\mathrm{TZP} に 20 \mathrm{wt} \% \mathrm{Al}_{2} \mathrm{O}_{3}$ を分散さ せた焼結体（東ソ一製，室温強度 $2400 \mathrm{MPa}$ ，以下 $3 \mathrm{Y}$ TZP-20 A と略す）上，比較のために $\mathrm{Al}_{2} \mathrm{O}_{3}$ 焼結体（相 対密度 $99 \%$ ，常圧焼結体）を併せて用いた。接合は $1000^{\circ} \mathrm{C}$, 昇降温速度 $4^{\circ} \mathrm{C} / \mathrm{min}$, アルゴン流通下で行った。 図 5 に熱処理時間と接合強度の関係を示す. $\mathrm{Al}_{2} \mathrm{O}_{3}$ 無添 加の $3 \mathrm{Y}-\mathrm{TZP}$ では, $30 \mathrm{~min}$ の処理により平均 $53 \mathrm{MPa}$, $3 \mathrm{Y}$-TZP-20 A では 0 min の処理で平均 $13 \mathrm{MPa}, \mathrm{Al}_{2} \mathrm{O}_{3}$ では平均 $6 \mathrm{MPa}$ の最高強度が得られた. 明らかに母材 に $\mathrm{Al}_{2} \mathrm{O}_{3}$ を添加することにより接合強度は顕著に低下し た.これは，母材の $\mathrm{ZrO}_{2}$ と $\mathrm{Ti}$ との間の熱膨張係数の 差に起因していると思われる. Ti の室温における熱膨 張係数は $8.5 \times 10^{-6} /{ }^{\circ} \mathrm{C}, 3 \mathrm{Y}-\mathrm{TZP}$ は $8.8 \times 10^{-6} /{ }^{\circ} \mathrm{C}$, $\mathrm{Al}_{2} \mathrm{O}_{3}$ は $6 \times 10^{-6} /{ }^{\circ} \mathrm{C}$ であり $\mathrm{Ti}$ と $3 \mathrm{Y}-\mathrm{TZP}$ との熱膨張 係数の差は非常に小さいのに対して $\mathrm{Al}_{2} \mathrm{O}_{3}$ との差は室温

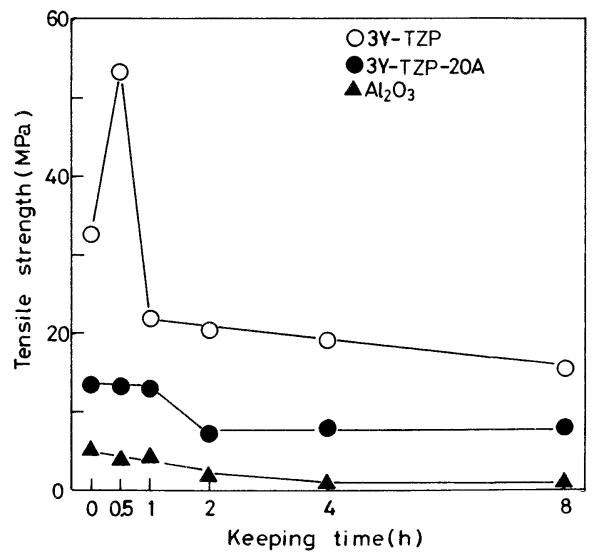

Fig. 5. Effect of $\mathrm{Al}_{2} \mathrm{O}_{3}$ addition to zirconia on bonding strength. 
において $2.5 \times 10^{-6} /{ }^{\circ} \mathrm{C}$ の差がある. $3 \mathrm{Y}-\mathrm{TZP} に \mathrm{Al}_{2} \mathrm{O}_{3}$ を分散させた場合, $\mathrm{Al}_{2} \mathrm{O}_{3}$ の持つ熱膨張係数の影響を直 接受け, Ti との膨張率の差が拡がるものと推察される。 そのため接合温度からの炩却過程で接合界面における熱 膨張係数の差に起因する熱応力を無視できず，この界面 に発生する残留応力が真の接合強度を相殺するためと思 われる. 特に $\mathrm{Al}_{2} \mathrm{O}_{3}$ と $\mathrm{Ti}$ との接合にわいては, 破断源 が $\mathrm{Al}_{2} \mathrm{O}_{3}$ 内部であったことからも示唆される. Suganu- ma らは2)有限要素法を用いて接合界面に発生する残留 応力の評価を行い, 特に熱膨張係数の差の著しい材料間 の接合では発生する熱応力だけでセラミックスは破壞す ることを示唆しており,この解決法としてインサート金 属の導入が最も適切であることを報告している，すなわ ち, $\mathrm{Al}_{2} \mathrm{O}_{3}$ を分散させたことにより，接合時の残留応力 を無視できないことがわかった。

次に，得られた接合体界面の組織観察並びに EDAX
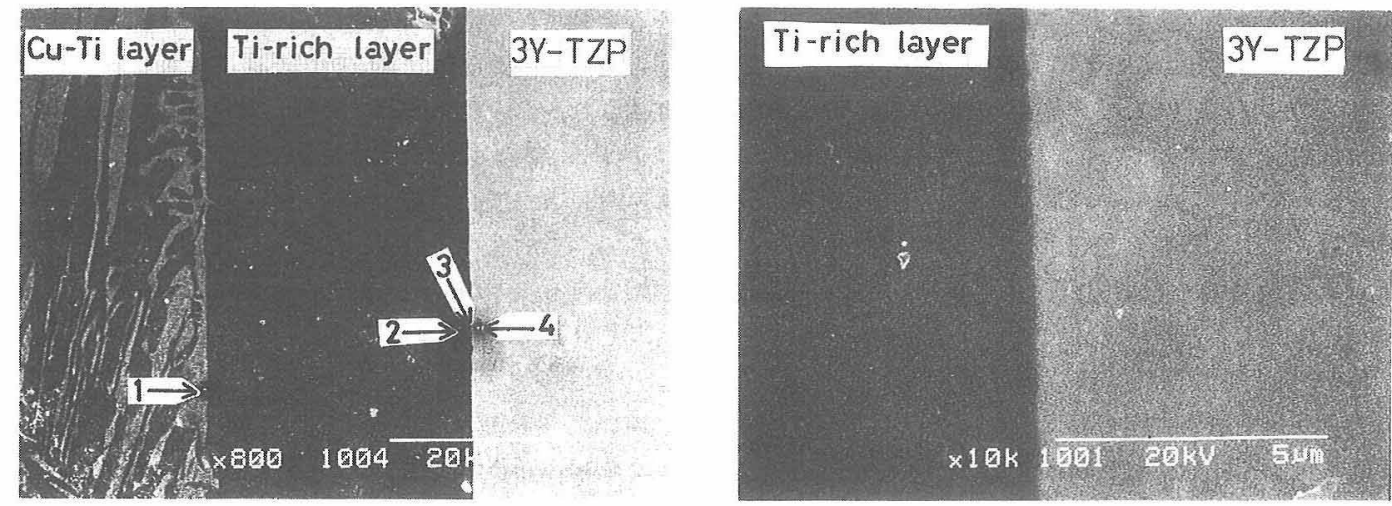

Fig. 6. Scanning electron micrographs of the bonded interface of the Ti/3Y-TZP joint heat-treated at $1000^{\circ} \mathrm{C}$ for $30 \mathrm{~min}$.
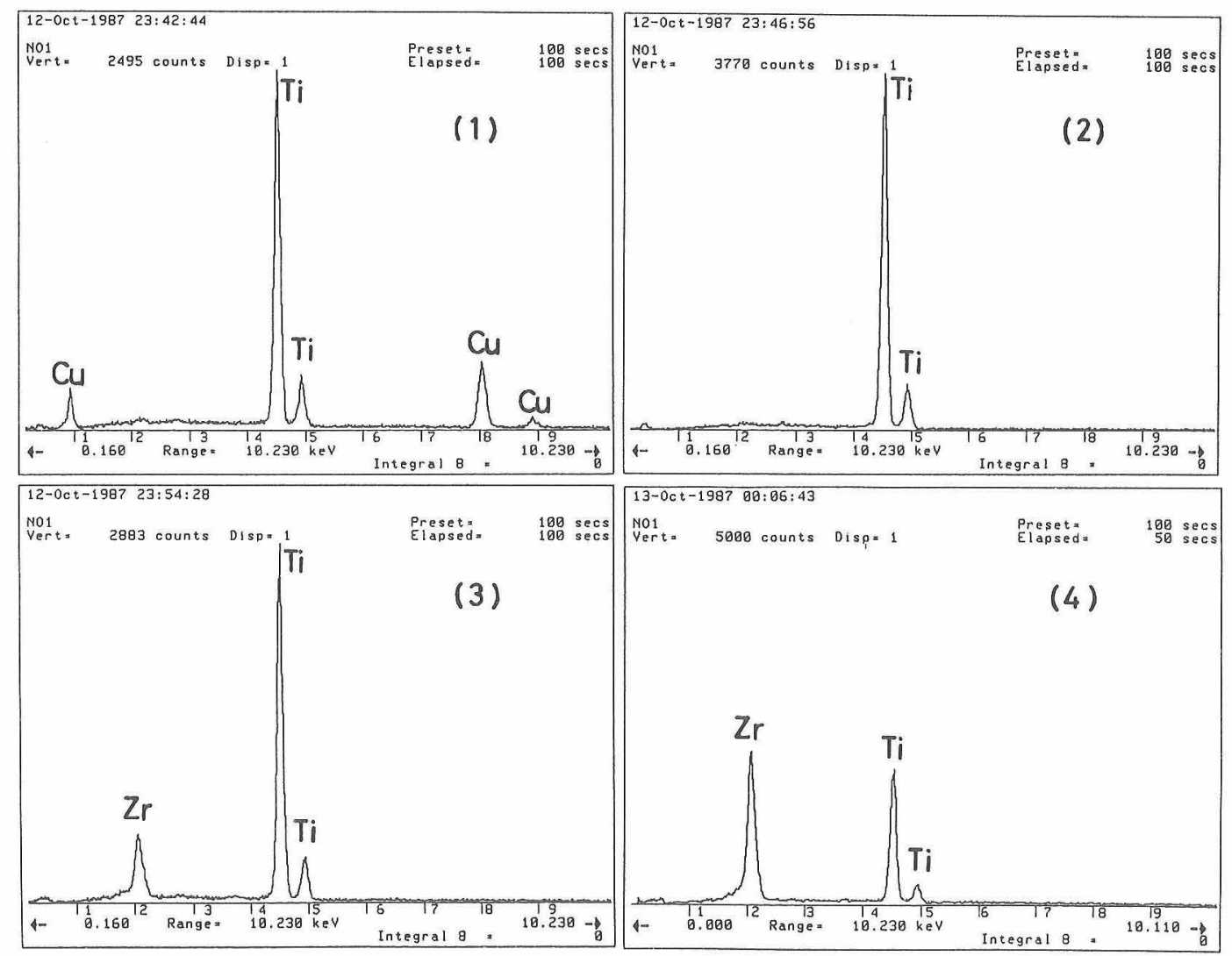

Fig. 7. EDAX profiles of the interface for Ti/3 Y. TZP joint. 
による元素分析を行った. 図 6 は Ti と $3 \mathrm{Y}-\mathrm{TZP}$ を $1000^{\circ} \mathrm{C} ， 30 \mathrm{~min}$ で接合した界面の SEM 像である。写 真加らわかるように金属側の組織は $\mathrm{ZrO}_{2}$ に接して Ti リッチ層が，更に内部に $\mathrm{Ti}$ と $\mathrm{Cu}$ との共晶組織が樹枝 状になって形成されている，PSPCにより界面化合物 を検出したところ, $\mathrm{Cu}$ - $\mathrm{T}$ i 共晶層には $\mathrm{CuTi}_{2}$ が， $\mathrm{Ti}$ リッ 于層には主成分の $\mathrm{Ti}$ 之微量成分の $\mathrm{Cu}_{2} \mathrm{Ti}_{4} \mathrm{O}$ が, そして $\mathrm{ZrO}_{2}$ に接して $\mathrm{TiO}$ や $\mathrm{Ti}_{2} \mathrm{O}$ な $\mathrm{Ti}$ の低次酸化物の形成 が確認された。この酸素源は $\mathrm{ZrO}_{2}$ 側からの拡散酸素之 思われる. 事実, 接合後の $3 \mathrm{Y}-\mathrm{TZP}$ 焼結体は黒化して おり, $\mathrm{ZrO}_{2}$ 中の酸素の一部が還元されたことを示すも のである。しかし， Ti と $\mathrm{ZrO}_{2}$ との反応物は検出されな かった. SEM 像から界面は非常に密接に接合されてい ることがわかる．Ti と $3 \mathrm{Y}-\mathrm{TZP}$ との接合で高強度を発 現する理由は，接合剤を塗布して熱処理する際に顕著な $\mathrm{Cu}$ 成分の $\mathrm{Ti}$ 側への拡散を生じる結果, $\mathrm{ZrO}_{2}$ 接合面に $\mathrm{Ti}$ 金属側からの拡散により Ti リッチ層を形成するため である. Ti リッチ層は $\mathrm{ZrO}_{2}$ との熱膨張係数差も純 $\mathrm{Ti}$ のそれよりわずかの $\mathrm{Cu}$ が含まれているため一層接近し ていると予測される。しかも， $\mathrm{ZrO}_{2}$ に隣接して $\mathrm{Ti}$ の低 次酸化物が形成されることで酸素によって $\mathrm{ZrO}_{2}$ と結合 しているものと思われる. Morozumi らは ${ }^{3)} \mathrm{Nb}$ と $\mathrm{Al}_{2} \mathrm{O}_{3}$ 亡の固相接合において, 界面に形成される $\mathrm{NbO}_{x}$ の酸素 が接合に寄与すると報告しており，岡本らは ${ }^{14)} 3 \mathrm{Y}$ $\mathrm{TZP}$ と鋼との固相接合に Ti シートを挿入して接合し ているが，この TZP と Ti の界面に形成される酸化物 層の厚さが強度を大きく左右するとしている。本接合法 においても，熱処理時間を増加させることによって強度 が大きく低下することがわかったが，これは $\mathrm{ZrO}_{2}$ 側か らの酸素の拡散による $\mathrm{Ti}$ の酸化物層の厚さが増加した ためであると思われる，この層の増加により，界面組織 が粗雑になることが SEM 観察によっても確認されてい る.このように，接合界面に形成される薄い酸化物層が 接合強度を大きく向上させることがわかった，そこで図 6 にある矢印の番号における EDAX による元素分析の 結果を図 7 に示す.（1）が $\mathrm{Cu}-\mathrm{Ti}$ 共晶層の部分で $\mathrm{Cu}$ と $\mathrm{Ti}$ のみのピークが確認され， (2) が $\mathrm{ZrO}_{2}$ に近い部 分の $\mathrm{Ti}$ リッチ層で $\mathrm{Ti}$ のみのピークがみられ，（3）が 接合界面部分で，(4) が界面に近い $\mathrm{ZrO}_{2}$ 内部の部分 である.（3）と（4）のピークから界面をはさんで主 に Ti 成分がミクロンオーダーの幅で $\mathrm{ZrO}_{2}$ 内部へ拡散 しているのがわかる。このように無加圧接合においても 接合界面からわずかの幅で $\mathrm{Ti}$ が拡散していることは， 接合時に界面状態が非常に活性な状態となっていること を示唆するものである。こうした拡散浸透によって Ti は $\mathrm{ZrO}_{2}$ との接合面にくさび状に入り組み，より強固な 接合界面の形成に寄与するものと思われる.

また，3Y-TZP-20 A と Ti とを $1000^{\circ} \mathrm{C} ， 30 \mathrm{~min}$ にお
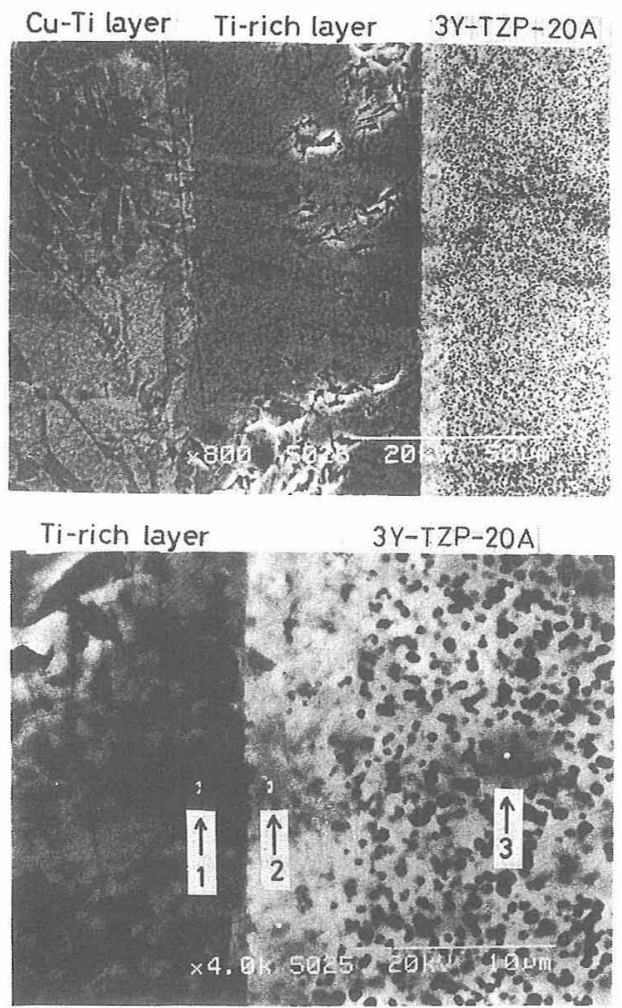

Fig. 8. Scanning electron micrographs of the bonded interface of the Ti/3Y-TZP-20 A joint heat-treated at $1000^{\circ} \mathrm{C}$ for $30 \mathrm{~min}$.

いて接合した際の界面のSEM 像を図 8 に示す.上の写 真が低倍率, 下の写真が接合界面部分の高倍率の写真で ある. $\mathrm{ZrO}_{2}$ 焼結体中に確認される黒点は分散した $\mathrm{Al}_{2} \mathrm{O}_{3}$ 粒子である. 界面の組織は $3 \mathrm{Y}-\mathrm{TZP}$ と $\mathrm{Ti}$ の接合 体とほぼ同じであったが，唯一異なるのは Ti リッチ層 がややポーラスな組織になっており，また，3Y-TZP$20 \mathrm{~A}$ と $\mathrm{Ti}$ リッチ層の界面において $\mathrm{ZrO}_{2}$ 側に幅 $5 \mu \mathrm{m}$ 程度にわたり変質層か汧成されたことである。この部分 を中心に図 8 の下の写真の矢印の番号の位置における EDAX による元素分析の結果を図 9 に示す。(1) が $\mathrm{ZrO}_{2}$ に隣接した $\mathrm{Ti}$ リッチ層の部分で, $\mathrm{Ti}$ 以外に $\mathrm{Al}$ 上 $\mathrm{Zr}$ のピークが確認された．（2）は変質層の部分で $\mathrm{Zr}$ と $\mathrm{Al}$ 以外に $\mathrm{Ti}$ と $\mathrm{Cu}$ のピークが確認され, 接合剂成分 と $\mathrm{Ti}$ 側からの拡散層といえる. (3) は $\mathrm{ZrO}_{2}$ 母材の部 分で $\mathrm{Al}$ と $\mathrm{Zr}$ の両ピークが確認された。変質層の部分 には，Al 成分が内部に比べて少ないことがわかる。こ れは，Tiリッチ層中に拡散してなくなった部分である. この変質層の部分の組織は非常に脆く, 破断源の組織観 察によりこの部分を中心に破壞したものと完全にセラ ミックス内部で破壊したものの二つの破壊モードがあっ た.こうして $\mathrm{ZrO}_{2}$ 中の $\mathrm{Al}_{2} \mathrm{O}_{3}$ 粒子の存在によって界面 の拡散状況も大きく異なり，上り一層，相互拡散が顕著 
になることがわかった。

\section{5 接合強度に及ぼす $\mathrm{ZrO}_{2}$ 母材密度の影響}

接合において問題となるのは，セラミックスが金属に 対してどの程度濡れ性があるかということで，セラミッ クスの母材密度に関してどの程度接合に寄与するかと いった報告例はない，そこで， $\mathrm{ZrO}_{2}$ 密度と接合強度の 関係について調査した. $1000^{\circ} \mathrm{C}, 30 \mathrm{~min}$, 昇降温速度 $4^{\circ} \mathrm{C} / \mathrm{min}$ の条件で接合した。結果を図 10 に示す。図か ら母材の焼成温度の向上に伴い， $1300^{\circ} \mathrm{C}$ まで接合強度
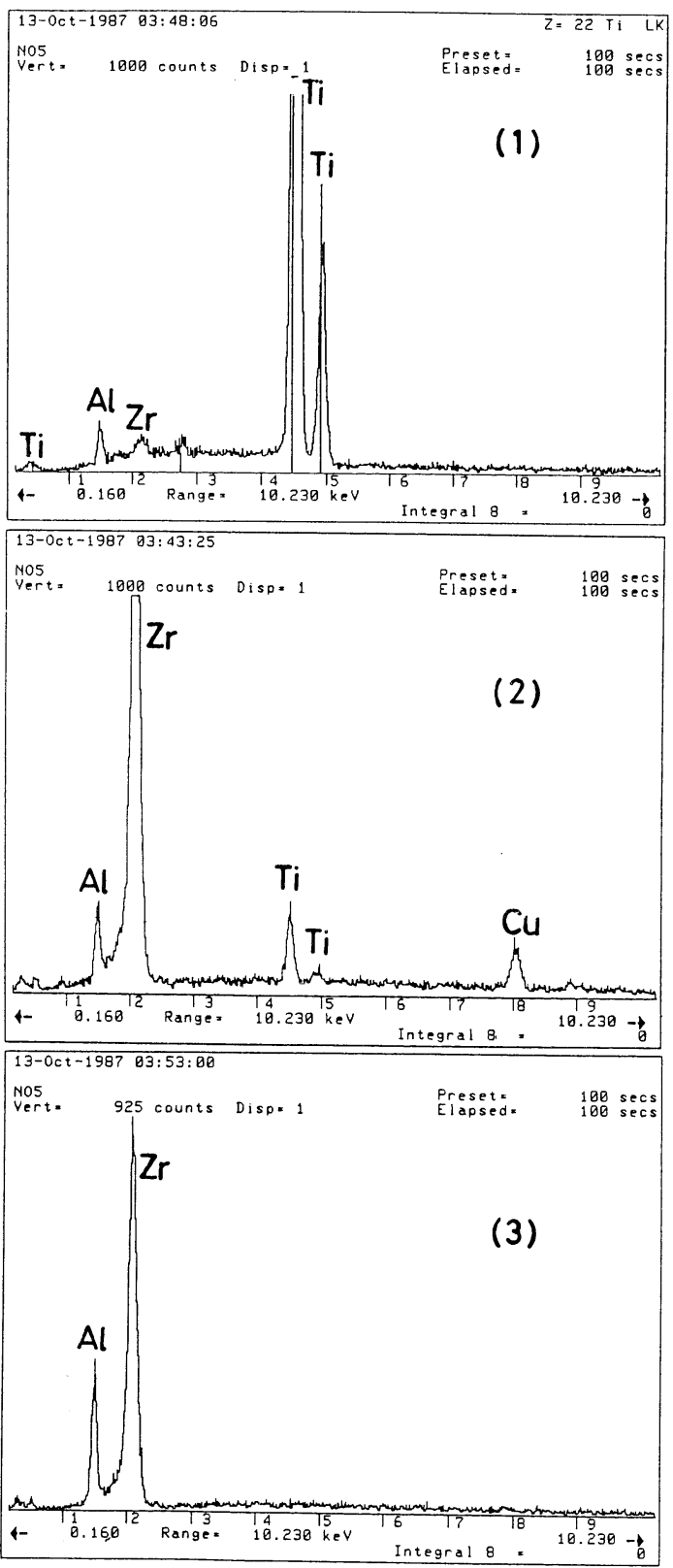

Fig. 9. EDAX profiles of the interface for $\mathrm{Ti} / 3 \mathrm{Y}$. TZP-20 A joint.
の増加を示すが， $1400^{\circ} \mathrm{C}$ で焼成した接合体（平均曲げ 強度 $1100 \mathrm{MPa}$, 硬度 $1150 \mathrm{~kg} / \mathrm{mm}^{2}$ ) の接合強度は 11 $\mathrm{MPa}$ まで減少した。しかし， $1500^{\circ} \mathrm{C}$ で焼成した接合体 の接合強度は母材密度がやや低下（相対密度 $99.4 \%$ ) するものの, 母材の中で最も良好な值 ( $53 \mathrm{MPa})$ になっ た.このことは母材の密度と関連しており，前者の母材 は相対密度がほぼ理論密度に近いために接合面は緻密な 組織になっていることが予測され，わずかの久陥等が界 面において有効に作用し，金属の濡れ性を促進させるこ とを示唆するものである. $1100^{\circ} \mathrm{C}$ で焼成したものは相 対密度 $91.4 \%$ とかなり低く接合面には多くの欠陥が存 在すると思われ，接触面積を低下させるため低い強度に すぎないと思われる，通常，接合材は機械的特性に優れ た高密度体を用いることが多いが，本研究ではやや機械 的特性に劣る $1500^{\circ} \mathrm{C}$ で焼成した母材（平均曲げ強度 $950 \mathrm{MPa}$, 硬度 $1100 \mathrm{~kg} / \mathrm{mm}^{2}$ ) が接合体としての強度が 優れているために十分に母材の特性をもカバーするもの

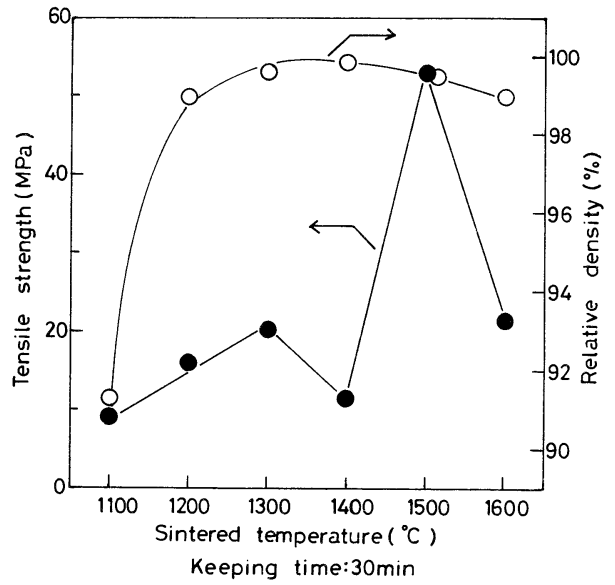

Fig. 10. Effect of density of 3 Y-TZP (sintering temperature) on bonding strength.

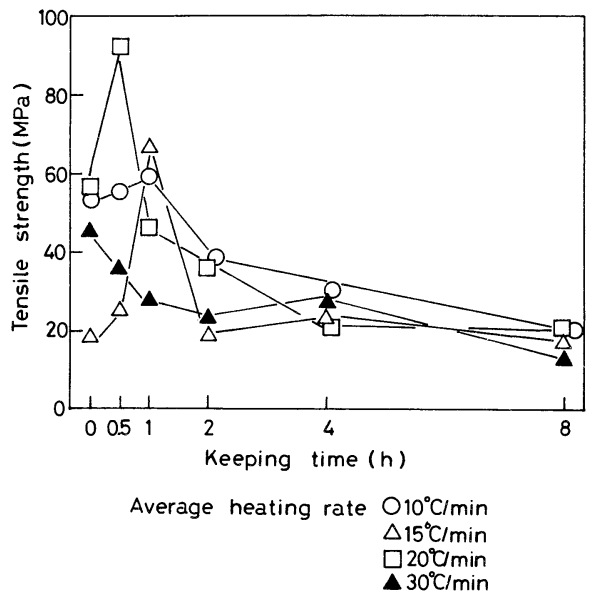

Fig. 11. Effect of heating rate on bonding strength. 
と考えられる. 以上のことより母材密度が接合強度に及 ぼす影響が大きく, $1500^{\circ} \mathrm{C}, 2 \mathrm{~h}$ の焼成体が最も適切な 母材であることがわかった。

\section{6 接合強度に及ぼす熱処理の際の昇降温速度の影}

\section{響}

今まで記述してきた接合体は，昇降温速度が $4^{\circ} \mathrm{C} / \mathrm{min}$ で極めて遅く, 実用的なものとは言えない. そこで 1 バッチに要する時間を短縮する目的で熱処理の 際の昇降温速度を変えて強度に及ぼす効果について検討 した. 接合温度は $1000^{\circ} \mathrm{C}$ と一定にした. 図 11 に結果 を示す. 昇降温速度 $4^{\circ} \mathrm{C} / \mathrm{min}$ では, $30 \mathrm{~min}$ の処理によっ て接合強度は平均 $53 \mathrm{MPa}$ であるが，昇降温速度を増 加させることによって徐々に強度が増加し, $20^{\circ} \mathrm{C} / \mathrm{min}$ の条件で最高の值が得られた，本接合法では，ビのよう な熱処理を行っても比較的短時間の $30 \mathrm{~min}$ 前後で最高 值が得られ, $20^{\circ} \mathrm{C} / \mathrm{min}, 30 \mathrm{~min}$ で平均 $93 \mathrm{MPa}$ の接合 強度が得られた。これは, 昇降温速度を増加させること によって接合剤中の $\mathrm{Cu}$ 成分の拡散を促進して，接合面 をより活性な状態にし， $\mathrm{ZrO}_{2}$ 中の酸素の拡散をある程 度抑制して適切な厚さの $\mathrm{Ti}$ 酸化物層を形成させたため と思われる。酸素の拡散層の厚さは数 $\mu \mathrm{m}$ 程度の薄いも のが有効であると推察される、昇降温速度を $20^{\circ} \mathrm{C} / \mathrm{min}$ とすることによって接合強度は $4{ }^{\circ} \mathrm{C} / \mathrm{min}$ のほぼ 2 倍向 上することが確認され，1 バッチに要する時間の短縮が 可能で極めて信頼性の高い接合体を合成できることがわ かった。

\section{7 接合強度に及ぼす $\mathrm{ZrO}_{2}$ の面粗さの影響}

接合においてセラミックス表面の表面研削状態が接合 強度に大きく影響を与える。そこで $\mathrm{Ti}$ 側の面粗さを一 定にして $\mathrm{ZrO}_{2}$ 表面の研削状沉が接合強度に及ぼす影響 について調査した。面粗さは $0.05 \mu \mathrm{m}$ のかに 0.2, 1.5, 3.0, $5.0 \mu \mathrm{m}$ のものを用意した.これらは研削方向に対

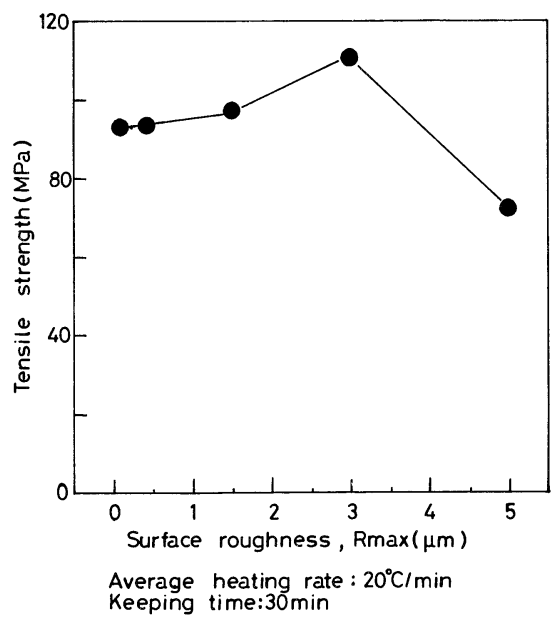

Fig. 12. Effect of surface roughness of $\mathrm{ZrO}_{2}$ on bonding strength.
して垂直方向について面粗さ計で測定したものである。 また, 粗さのばらつきを考慮して試験用試料はすべて平 均值を示している。接合は, 昇降温速度 $20^{\circ} \mathrm{C} / \mathrm{min}, 30$ $\min$ の最適条件で行った。結果を図 12 に示す。図より 明らかに面粗さのある程度粗い方が強度を高めることが わかる. 面粗さ $3 \mu \mathrm{m}$ まで強度は徐々に増加していき, $3 \mu \mathrm{m}$ で強度 $110 \mathrm{MPa}$ に達し，この条件で接合した試料 のいくつかはこの強度で破断しなかったために更に強度 は高いものと思われる. しかし, $5 \mu \mathrm{m}$ になると強度の 急激な低下を示した. 以上のことより面粗さは $3 \mu \mathrm{m}$ 程 度まで効果的に金属の接触あるいは濡れ性に寄与する が， $3 \mu \mathrm{m}$ 以上では反対に接合面における有効接触面積 を低下させ強度の低下の要因になるものと思われる。菅 沼らの報告では15)，金属側の面粗さを一定にした場合， セラミックスの面粗さは滑らかなものほど強度が増加す るとしているが, 本研究ではやや粗い方が強度の向上が 確認された。これは, 接合方法が異なるためで, 固相接 合では加圧によって金属の塑性変形を界面領域に起こし て接合するために，なるべく接合面積を大きくするため 接合面を円滑にする方が効果的であると思われる. しか し本接合法では, 反対にやや粗い試料で強度が発現した 理由として無加圧接合では，接合面を粗くすることで界 面の凹凸が噛み合って接合されるためと考えられる．以 上のことより, $\mathrm{ZrO}_{2}$ 接合面には $3 \mu \mathrm{m}$ 程度の粗さが適 切であり通常鏡面仕上げして調製する試料に比べて研削 時間を短縮する効果があることがわかった。

\section{8 接合体の各種雾囲気における熱安定性}

得られた接合体の各種雾囲気における熱安定性を調査 するため, 接合体を昇温速度 $45^{\circ} \mathrm{C} / \mathrm{min}$ で急速加熱して 所定温度及び時間保持した後, 急速冷却し, 室温に達し たものの接合強度を測定した。用いた接合体は，B 級 $\mathrm{Ti}$ 金属を昇降温速度 $20^{\circ} \mathrm{C} / \mathrm{min}, 1000^{\circ} \mathrm{C}, 0 \mathrm{~min}$ で接合

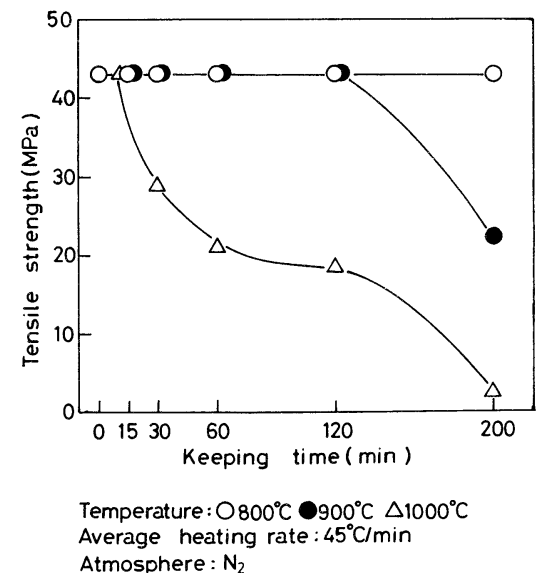

Fig. 13. Thermal stability in $\mathrm{N}_{2}$ of the Ti/3 Y-TZP joint heat-treated at $1000^{\circ} \mathrm{C}$ for 0 min. 
した平均接合強度 $43 \mathrm{MPa}$ ののである. 窒素雾囲気 中における熱安定性を調査した結果を図 13 に示す.図 から, 窒素雾囲気中において $800^{\circ} \mathrm{C}$ まで全く強度劣化 が見られず, $900^{\circ} \mathrm{C}, 200 \mathrm{~min}$ 保持してもほぼ 2 分の 1 の強度を保持していることがわかった，しかし， $1000^{\circ} \mathrm{C}$ では $15 \mathrm{~min}$ でも強度が低下する傾向が見られ た. 接合強度の低下は, 接合界面に形成される $\mathrm{Ti}$ リッ チ層の窒化と関連がある. すなわち, 接合面に TiN や $\mathrm{Ti}_{2} \mathrm{~N}$ が生成して接合界面組織を脆くするために強度が 低下することがわかった。

一方，空気中では温度 $400^{\circ} \mathrm{C}$ まで，アルゴン雾囲気 中においては $1000^{\circ} \mathrm{C}, 200 \mathrm{~min}$ 保持しても全く強度劣 化のない優れた熱安定性を有することがわかった．急速 加熱及び冷却によって熱安定性試験を行っているために 接合体には熱衝撃の影響も加味されると予測されるが, それでもかなり高温まで安定性の高い接合体であること がわかった。

\section{$3.9 \mathrm{Ti} / 3 \mathrm{Y}-\mathrm{TZP}$ 接合のメカニズム}

接合界面の組織観察及び元素分析, 界面化合物の検出 及び同定によって Ti/3Y-TZP 接合メカニズムについて 考察した. 図 14 に Ti/3Y-TZP 接合メカニズムの模式 図を示す。最初の段階は接合剤を間にはさんだ状態で熱 処理前である.この状態から, 熱処理温度 $800^{\circ} \sim 900^{\circ} \mathrm{C}$, アルゴン中にて処理すると, 接合剤の酸化物成分の酸素 は還元剤によって $\mathrm{CO}_{2}$ ガスとなって反応系外へ除かれ て金属 $\mathrm{Cu}$ が生成する。この温度では殆ど接合強度を発 現せず， $\mathrm{Cu}$ の拡散や反応は生じない． $950^{\circ} \mathrm{C}$ では $\mathrm{Cu}$ 成分が主に $\mathrm{Ti}$ 側へ拡散し始め, 一部において $\mathrm{Ti}$ と $\mathrm{Cu}$
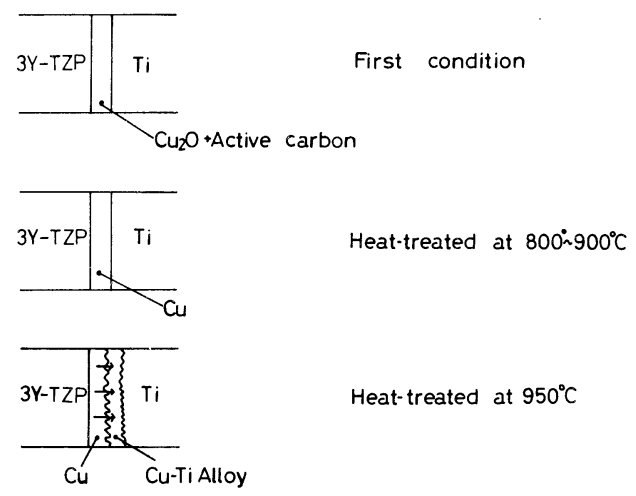

Heat-treated at $950^{\circ} \mathrm{C}$

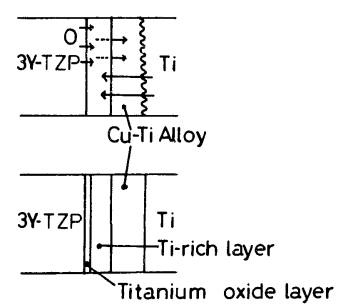

Fig. 14. Bonding mechanism of Ti/3 Y-TZP system.
の反応物である $\mathrm{CuTi}_{2}$ を生成する. $\mathrm{CuTi} \mathrm{T}_{2}$ は $\mathrm{Cu}-\mathrm{Ti}$ 系 状態図から液相状態となることより Cu の拡散過程で形 成される $\mathrm{Ti}$ リッチ層と $\mathrm{Cu}-\mathrm{Ti}$ 合金層との間に強い結合 を生じさせるものと思われる。このことは，接合体の破 断状態を観察した結果, 破断が $\mathrm{ZrO}_{2}$ と $\mathrm{Ti}$ リッチ層の 界面で生じたことからも示唆される.この段階では, 完 全に $\mathrm{Cu}$ 成分の拡散が生じず $\mathrm{ZrO}_{2}$ 表面に $\mathrm{Cu}$ が残留し 十分な接合強度に至っておらず接合の変移過程と言え る. 次に $1000^{\circ} \mathrm{C}$ では $\mathrm{Cu}$ 成分の $\mathrm{Ti}$ 中への拡散が一層 活発になり，一方的な $\mathrm{Cu}$ の拡散に伴って Ti 内部から $\mathrm{Ti}$ 成分の拡散が生じる.ここで初めて $\mathrm{ZrO}_{2}$ 表面に $\mathrm{Ti}$ リッチ層が形成される。 また, Ti リッチ層の形成之同 時に $\mathrm{ZrO}_{2}$ 表面から一部酸素の拡散によって $\mathrm{Ti}$ の低次 酸化物を生成して接合力を高め, 接合強度の増加に寄与 する. 最終的に接合界面の組織は以下のようになること がわかった。

$\mathrm{ZrO}_{2} / \mathrm{Ti}$ 低次酸化物層/ $\mathrm{Ti}$ リッチ層/ $\mathrm{Cu}-\mathrm{Ti}$ 合金層 $/ \mathrm{Ti}$ 金属

ここで重要なことは, $\mathrm{Cu}$ の拡散に伴って $\mathrm{ZrO}_{2}$ 表面 にTiリッチ層を形成したことと $\mathrm{ZrO}_{2}$ 側からの酸素の 拡散を伴い一部 $\mathrm{Ti}$ の低次酸化物が生じたことである. $\mathrm{Ti}$ リッチ層は $\mathrm{ZrO}_{2}$ に熱膨張係数が比較的近いため接合 時における残留熱応力を軽減でき, しかも $\mathrm{ZrO}_{2}$ 接合面 に Ti の低次酸化物を形成することで酸素による結合力 の増加が計れるためである. 以上より通常ろう接法はろ う材の組成に対して非常に厳密であるため用いる接合剂 の選択に注意を要する. しかし，本接合法では特に接合 剤に対してそれほど注意を払う必要はなく, 生成する $\mathrm{Cu}$ の主に金属側への拡散によって Ti の接合面に対し 自然に接合面に馴染むので，極めて実用的方法であるこ とがわかった。

\section{4. 総 括}

本研究では金属として比較的汎用性の高い金属 $\mathrm{Ti}$ 亡 酸化物セラミックスの中でも高強度, 高鞁性セラミック スとされる $3 \mathrm{Y}-\mathrm{TZP}$ との接合を無加圧下, アルゴン雾 井気中で接合できた。以下に得られた結果についてまよ める.

（1）接合剤として $\mathrm{Cu}_{2} \mathrm{O}$ に $5 \mathrm{wt} \%$ 活性炭を添加し たものを用いて接合すると, 昇降温速度 $4^{\circ} \mathrm{C} / \mathrm{min}$ で,

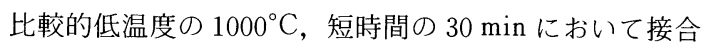
強度が平均 $53 \mathrm{MPa}$ に達した。

（2）接合強度に及ぼす各種パラメーターの中で, 重 要であるのは合成雾囲気, $\mathrm{Ti}$ の純度, 接合時の昇降温 速度, $\mathrm{ZrO}_{2}$ の面粗さであった.

(3) アルゴン雾囲気下, $1000^{\circ} \mathrm{C}, 30 \mathrm{~min}$, 昇降温 速度 $20^{\circ} \mathrm{C} / \mathrm{min}, \mathrm{ZrO}_{2}$ 面粗さ $3 \mu \mathrm{m}$ の条件で接合すると, 接合強度は $110 \mathrm{MPa}$ 以上に達することがわかった。 
（4）得られた接合体の熱安定性を調べた結果, 空気 中において $400^{\circ} \mathrm{C}$, 窒素雾囲気中において $800^{\circ} \mathrm{C}$, アル ゴン雾囲気中において $1000^{\circ} \mathrm{C}$, 時間 $200 \mathrm{~min}$ 保持して も全く強度劣化のない優れた熱安定性を有する接合体で あることがわかった。

本接合法では, 特に試料調製の際や，合成時に特殊な 処理を行わなくても，極めて簡便な方法で信頼性の高い 比較的高強度の接合体を合成でき，実用的な方法である ことがわかった。

\section{文献}

1) K. Suganuma, T. Okamoto, M. Shimada and M. Koizumi, J. Am. Ceram. Soc., 66, C 117-18 (1983).

2) K. Suganuma, T. Okamoto, M. Shimada and M. Koizumi, J. Am. Ceram. Soc., 67, C 256-57 (1984).

3) S. Morozumi, M. Kikuchi and T. Nishio, J. Mater. Sci., 16, 2137-44 (1981).

4) F.P. Bailey and K. J. Black, J. Mater. Sci., 13, 1045-
52 (1978)

5) M. Nicholas, J. Mater. Sci., 3, 571-76 (1968).

6) N. G. Nicholas and R. M. Crispin, J. Mater. Sci., 17, 3347-60 (1982).

7) R. V. Allen and W.E. Borbidge, J. Mater. Sci., 18, 2835-43 (1983).

8) M. Wittmer, C. R. Born and P. Gudmundson, J. Am. Ceram. Soc., 65, 149-53 (1982).

9) R. V. Allen, W. E. Borbidge and P. T. Whelan, "Advances in Ceramics", Vol. 12, Am. Ceram. Soc., Inc., Columbus, Ohio (1984) pp. 537-43.

10) K. Tsukuma, Y. Kubota and T. Tsukidate, "Advances in Ceramics", Vol.12, Am. Ceram. Soc., Inc., Columbus, Ohio (1984) pp. 382-90.

11）小暮英治, 野口文雄, 飯田武揚, 三田村 孝, 窯業協会 昭和 62 年度年会講演予稿集, 第三分冊 (1987) p. 1077.

12）小暮英治, 松本直樹, 野口文雄, 飯田武揚, 三田村 孝, 第 26 回窯業基礎討論会講演予稿集 (1988) p. 117.

13) R.E. Cowan, 米国特許 3, 180, 756 (1965-4-27).

14）岡本 平, 菅沼克昭, 昭和 60 年度日本金属学会分科会シ ンポジウム講演予稿集（1985）p.11.

15）菅沼克昭, 岡本 平, 小泉光恵, 永田京一郎, 合田 進, 第 25 回窯業基礎討論会講演予稿集 (1987) p. 149. 